\title{
João José Reis. Domingos Sodré, um sacerdote africano: escravidão, liberdade e candomblé na Bahia do século XIX
}

Durval Muniz de Albuquerque Júnior*

São Paulo: Companhia das Letras, 2008. 461p.

João José Reis é merecidamente um figurão da historiografia brasileira. Seus livros, desde o pioneiro Rebelião escrava no Brasil, modificaram o estado da arte dos estudos sobre escravidão, sobre rebelião escrava e movimentos sociais, não só no país, mas internacionalmente. Esse pesquisador meticuloso e apaixonado, esse amante dos arquivos, das bibliotecas, dos documentos e dos livros acaba de lançar mais uma obra, um livro já saudado efusivamente em várias resenhas de especialistas no campo dos estudos sobre escravidão, no campo da chamada História Social: Domingos Sodré, um sacerdote africano. O livro se propõe a fazer um exercício de micro-história, pois toma como fio condutor da análise a vida de um africano liberto que viveu na Bahia do século XIX, e a partir da biografia desse ex-escravo que se tornou uma importante figura entre a população africana da cidade, desse sacerdote preso por ser acusado de práticas religiosas heréticas e diabólicas, o autor traça um amplo panorama das intrincadas relações sociais, das relações de poder, das atividades econômicas e culturais vivenciadas pelos libertos, por essa parte da população que, vivendo nas fímbrias do sistema escravista, sendo resultado dele, mas em muitos aspectos a ele se opondo, é pouco levada em conta quando se trata de contar a história da escravidão brasileira. A trajetória do liberto, do papai Domingos Sodré, que provavelmente nasceu em Onim ou Lagos, na atual Nigéria, por volta do ano de 1797, que morreu em 1887, com estimados noventa anos de idade, que deve ter desembarcado na Bahia, como escravo, entre os anos de 1815 e 1820, até por sua longevidade, por ter atravessado quase todo o século e por ter transitado entre as condições de escravo e de

\footnotetext{
* Centro de Ciências Humanas Letras e Artes, Universidade Federal do Rio Grande do Norte (UFRN). Pesquisador CNPq. Departamento de História - Campus Universitário, BR-101, Lagoa Nova. 59078-970 Natal - RN - Brasil. durvalal@pesquisador.cnpq.br.
} 
homem livre, permite pensá-lo como um sujeito encruzilhada, sujeito que foi se constituindo e se transformando à medida que transitava por distintos territórios sociais e culturais, que elaborou e vestiu distintas máscaras identitárias, que encarnou distintos lugares de sujeito, que entrou em conflito e teve de negociar com distintas forças e personagens sociais, que conviveu, fez parte e recorreu a distintas instituições sociais, tanto formais como informais, que fez parte tanto do mundo dos pretos, da cidade negra, quanto dos brancos, da cidade oficialmente dita branca e aristocrática. Através de sua vida, João Reis tentou acompanhar as pistas que levam à presença e à prática do candomblé, na Bahia do século XIX, bem como dar conta da dura repressão que ele sofria, em dados momentos, por parte das autoridades policiais e judiciais, e como, ao mesmo tempo, essas práticas conseguiam resistir e sobreviver por terem, muitas vezes, o apoio de membros das elites e até mesmo das próprias autoridades que deviam combatê-las.

No que tange à contribuição deste livro para o estudo da escravidão, da liberdade e do candomblé, outros autores já se manifestaram e não sou eu o mais habilitado para avaliá-la, já que não sou especialista no tema, nem milito no campo da História Social. Os motivos que me levam a resenhar esta obra, a indicá-la, portanto, como leitura obrigatória para todos os historiadores, independentemente do tema com que se ocupem, do campo da disciplina em que militem, é que a considero uma obra exemplar do que seriam, hoje, as regras que presidem a operação historiográfica; considero-a uma obra exemplar na observância dos procedimentos que dariam estatuto científico ao nosso ofício, mas também a considero exemplar no que tange aos impasses, aos dilemas, aos debates acalorados que dividem, nestes dias que correm, a comunidade dos historiadores. Assim como aborda um sujeito encruzilhada, ela é, também, uma obra onde as encruzilhadas em que está colocado nosso ofício emergem com nitidez. Ela é uma obra exemplar do caráter narrativo da historiografia, do papel que a narrativa desempenha na elaboração e inscrição da história; é obra exemplar das artes e artimanhas que são requeridas de todo historiador, na hora que tem de transformar a pilha de documentos compulsados, as inúmeras pistas e rastros encontrados, num enredo que faça toda essa poalha, essa dispersão, fazer sentido; ela é exemplar do uso do que alguns preferem chamar de imaginação histórica, para não dizer o uso da ficção na escrita da história, ficção entendida não como o oposto da verdade ou da realidade, mas como a capacidade poética humana de dotar as coisas de sentido, de imaginar significados para todas as coisas, sentidos que são sempre, em última instância, uma invenção humana, já que as coisas não trazem em si 
mesmas um único significado, nem gritam ou dizem o que significam. As evidências nem falam, nem são evidentes; elas são levadas a dizer algo por quem as diz, elas são levadas a serem vistas por quem as põe em evidência.

Em várias passagens do livro, o caráter lacunar das fontes, a falta de documentos sobre a vida de Domingos Sodré e o silêncio dos arquivos sobre a vida dos de baixo obrigam João Reis a imaginar, a ficcionar, a tentar adivinhar como poderia ter sido, o que poderia ter acontecido com o papai Sodré e seus companheiros de condição na cidade da Bahia, em tal ano e em tal situação. Ele não se contém em imaginar que papai Domingos poderia ter estado em dado lugar, conhecido alguns de seus vizinhos, participado de dadas cerimônias, conhecido algumas autoridades, tivesse tomado algumas medidas, sabido de dados eventos e notícias, sempre fazendo questão de deixar claro, nesses momentos, como pesquisador sério e honesto que é, que se tratava de viagens ou visagens de sua própria lavra. Imaginação, ficção que na historiografia é limitada pelas próprias informações que se tem, pelo conhecimento que o historiador tem do período que estuda, por aquilo que sabe sobre o funcionamento da sociedade e da cultura que está estudando. Imagina-se o provável, ficciona-se o possível de ocorrer naquele tempo e lugar, com as pessoas que vivem em dada situação social e segundo dados códigos culturais. No entanto, sem essa capacidade de imaginar, sem a habilidade de criar, de inventar sentidos e significados para os restos do passado que chegam até o presente, a historiografia seria impossível. O próprio João Reis admite o parentesco existente entre o historiador e o adivinho. $\mathrm{O}$ historiador, às vezes, também tem que ser um papai, tem que jogar os coloridos búzios das significações que acha possível serem dadas a um evento, tem que exercer suas artes divinatórias, deixar a intuição trabalhar, estabelecer ligações entre os eventos que não estão explicitadas na documentação. Afinal, faz certo tempo que os historiadores sabem que os documentos não dizem tudo e que eles são capazes de provar as teses mais díspares, dependendo dos significados que a eles se atribuem, da leitura que deles se faz.

No epílogo do livro, João Reis vai fazer uma afirmação que é muito reveladora da própria consciência que o autor tem da importância da narrativa, da construção do texto para a versão da história que constrói. Estamos muito longe, aqui, de certa visão ingênua de que é possível estabelecer uma versão definitiva dos eventos e que essa seria a verdadeira versão do passado. $\mathrm{O}$ autor vai afirmar que se as informações que se tinha sobre um figurão popular como Domingos Sodré eram poucas e esparsas, o que se sabia sobre a vida de Maria Delfina da Conceição, que foi sua esposa por cerca de dezenove anos, 
era ainda menos expressivo. Essa mulher que acompanhou os passos, que dividiu a vida, a casa e possivelmente a crença com o papai, deixou pouquíssimos rastros de sua passagem pela história. Se soubéssemos mais sobre ela, diz Reis, o enredo dessa história poderia ser diferente. Nessa passagem, o autor admite, explicitamente, que a história que acabou de contar tinha um enredo: ela foi enredada, tramada, os eventos foram interligados por uma atividade narrativa, por uma arte de contar história. Ao contrário do que alguns historiadores ainda supõem, o enredo da história de Domingos não foi descoberto, encontrado pronto nos arquivos pelo historiador baiano. Ele não está no próprio passado, embora este seja uma referência para criá-lo, embora pequenos pedaços de enredos, pequenas tramas, também narrativas, também escritas tenham chegado até nosso pesquisador. O que Reis está afirmando é que o enredo foi feito no presente, por ele, com as informações que encontrou. Se ele afirma que o enredo poderia ser outro, não é que a história em si mesma pudesse ser outra. Sabemos que o passado não pode mais ser alterado pelo simples fato de que passou, mas o enredo poderia ser outro, pois, de posse de outras informações, de informações sobre a vida da companheira de Domingos, ele poderia escrever a história que escreveu de outro modo, o livro poderia ser diferente do que este que está publicado. A estratégia narrativa podia ser outra, outras as personagens, outras as ligações entre os eventos, outras as tramas, outras as explicações e significações.

O livro Domingos Sodré, um sacerdote africano é uma obra modelar no uso das artes, artimanhas e mandingas de nosso ofício, por isso deve ser bibliografia obrigatória nos cursos de metodologia da pesquisa histórica. Nele estão presentes todas as regras que presidem a operação historiográfica e que permitem que nosso ofício reivindique o estatuto científico: a narrativa mediante documentos; a pesquisa ampla e meticulosa de arquivo, onde o autor expõe nosso parentesco com os detetives; a crítica rigorosa das fontes; o concurso de uma ampla bibliografia na área de estudos a que pertence, incluindo desde obras clássicas, até obras mais recentes, trabalhos sequer publicados; um domínio fino da teoria e da metodologia faz com que ela sustente a análise, esteja presente na carpintaria, na estruturação do texto e de todos os passos da pesquisa, sem que precise aparecer atravancando o texto, em digressões que costumam ser xaroposas e pedantes. Essa leveza, essa fluência, essa beleza do texto, que já fez de Reis um autor premiado, é parte desta outra dimensão inseparável da operação historiográfica, aquilo que Certeau nomeou de escrita, a dimensão artística de nosso ofício, a dimensão ficcional que a narrativa histórica convoca. O bom livro de história, o clássico em nossa área não se faz 
apenas às custas do tema que se escolhe e da pesquisa documental que se faz, pois a história só existe quando escrita, é no texto que ela se realiza, bem ou mal. Afirmo, e talvez ele nem considere isso um elogio, que grande parte do sucesso dos livros de João Reis se deve à forma como são escritos, à sua habilidade narrativa, a despeito de serem todos fruto de exaustiva pesquisa e do estudo metódico e rigoroso de temas inovadores, muitos deles pouco tratados ainda.

João José Reis possui uma consciência da centralidade da narrativa em nosso ofício, como poucos. Seus livros explicitam as estratégias narrativas que escolheu. Domingos Sodré é um livro que, se fôssemos adotar as sugestões de Hayden White, diríamos vazado no enredo romanesco. É uma trama em que embora Domingos opere como uma metonímia de seu tempo, bem a gosto da micro-história italiana, que inspira teoricamente e metodologicamente o livro, ele é descentrado e disperso por uma dezena de outros personagens que vêm ocupar o seu lugar na trama sempre que as informações sobre ele escasseiam. João Reis deixa explícito que irá adotar na narrativa esse procedimento analógico. Como num romance, o livro de Reis não é um livro de teses, embora defenda algumas ideias, aliás faça algumas conclusões, mas estas não aparecem explicitadas, e sim implícitas, imanentes à trama que ele arma. Ele convoca a nós, leitores, a que cheguemos às conclusões antes que ele as exponha, a partir do enredo que ele elabora. Ele homenageia a inteligência dos leitores, jogando no tabuleiro os seus Fás para que a gente os decifre, para que leiamos a mensagem que quer nos fazer chegar. Em vários momentos da obra, a metonímia Domingos é substituída por outros personagens que atuam como se fossem metáforas do velho sacerdote, outros personagens ocupam o lugar desse sujeito e o dispersam, fazendo-o aparecer com diferentes rostos, em diferentes corpos, em diferentes situações, para em seguida, em outro movimento, tal como ocorre com o Menocchio de Carlo Ginzburg, em quem parece se inspirar, deixar de ser um ser singular, único, para ser um sujeito exemplar, um sujeito resumo de seu tempo, de sua sociedade e de sua cultura. Sua figura, que se dispersa num primeiro momento, no segundo momento unifica, homogeneíza, encarna a situação do liberto na Bahia, no século XIX. Em ambas as situações o caráter ficcional do procedimento é notório, para o mau humor do historiador italiano, que não cessa de fazer diatribes azedas contra a presença da ficção no ofício do historiador. Mas sem a ficção não haveria trama, não haveria enredo, não haveria compreensão, não haveria saber histórico. Tanto no momento em que outros libertos vêm agir, se comportar, falar, como Domingos, tanto no momento em que o autor supõe que 
se um liberto realizava tais práticas, o papai como um liberto que era também possivelmente fazia a mesma coisa, passava pela mesma situação, quanto no momento em que o sacerdote singular, excepcional, tão único que chegou a merecer biografia escrita por outro figurão da cidade, torna-se um representante de todos os libertos, que sua vida se torna similar à de todos de sua condição, que suas práticas de crença se tornam análogas às de outros praticantes desses rituais, é a imaginação, é a ficção, é a capacidade de dar sentido, de raciocinar por imagens, por figuras, de estabelecer configurações, por parte do historiador, que está agindo. É o historiador João Reis que está produzindo esse enredo, essa versão para o passado, a partir de seu olhar: um olhar formado pela disciplina histórica, pelas regras da disciplina, um olhar informado por dados pressupostos teóricos, um olhar informado por dadas posturas políticas, éticas e morais, e, por que não admiti-lo, um olhar constituído por dados códigos estéticos, por uma dada maneira de figurar o mundo, de vê-lo e de dizê-lo, um olhar tropológico, além de ideológico. A história é um saber de encruzilhada entre o fato e a ficção, entre o feito e o contado, entre a ação e a narração, entre o que se vê e o que se imagina, entre o rastro e o sonho, entre o resto e o desejo, entre o que se lembra e o que se esquece, entre o achado e o perdido, entre a fala e o silêncio, entre o signo e a significação, entre o material e o etéreo, entre os homens e todos os deuses.

Portanto, Domingos Sodré, um sacerdote africano é um bom exemplo de como a "história vista de baixo" é uma impossibilidade, já que ela, como todas aquelas escritas por historiadores, é fruto do olhar do historiador e não do personagem que nela é tratado. No livro de João Reis não lemos a história contada do ponto de vista de Domingos, até porque este está morto e quase nada pode nos dizer para além do pouco que ficou registrado, sempre por outras pessoas, pois, como é comum entre os de baixo, na época tratada por Reis, ele era iletrado, e até os documentos que registram sua presença são escritos e assinados por outros. A história é vista por Reis, não por Domingos, embora caiba ao historiador, esta é uma das mandingas do ofício, tentar adivinhar, imaginar, fabular, idear, intuir o que pensava e sentia o papai. Talvez, quem sabe, João Reis até gostaria de ser um cavalo em que viesse se encarnar o papai Domingos, o mandingueiro famoso, mas, nas artes divinatórias da história, quem frequenta essa encruzilhada costuma fazer seus próprios despachos, encomendar seus próprios feitos e contados. João Reis faz, como todas, uma "história vista de cima", já que, pelo menos até hoje, em nossa sociedade, os historiadores costumam ocupar os estratos considerados superiores da sociedade. É ele quem olha para Domingos do alto de sua sabedoria, de sua posição 
social, de seu lugar institucional, de seu lugar de classe, de seu lugar de letrado e doutor, de seu lugar de branco, né meu rei! Sobre a vida do velho sacerdote joga sua rede discursiva, o aprisiona em dados sentidos que estão agora à disposição da comunidade de historiadores para que sejam discutidos, debatidos, repensados, refeitos, reabertos a novas interpretações, a novas invenções. Mas, por isso mesmo, o velho mandingueiro baiano virou de vez figurão, passou a fazer parte da história do país, da história desta ignomínia, desta chaga que não pode deixar de ser reaberta para que continue doendo na consciência dos homens que foram capazes e ainda são capazes de perpetrá-la: a escravidão. Só por isso a invocação e a evocação do preto velho, a sua reencarnação narrativa nas páginas deste livro magistral, escrito por um mestre do ofício de historiar, que pode botar banca como seu personagem negro fazia na cidade da Bahia, já é merecedora de elogios e de leitura atenta. E quando tal intenção política e tal postura ética dão origem a uma narrativa primorosa como o deste Domingos Sodré, deve ser motivo de recomendação, não apenas para todos os santos, não apenas para todos os iniciados nas artes e ofícios da historiografia, mas principalmente para os neófitos, os que ainda estão realizando os atos preparatórios para entrar na nossa seita, os que ainda não estão de cabeça feita, que precisam passar pelos rituais de introdução a este fascinante mundo do sacerdócio, por isso mal remunerado, em nome do passado. Aceitem o sorriso convidativo do autor em sua rede e se enredem no fascínio deste livro escrito com competência científica e sensibilidade artística.

Resenha recebida em fevereiro de 2009. Aprovada em fevereiro de 2009. 